\title{
FUTURE DAVOS FORUM IN KYRGYZSTAN
}

Review. This article is intended to clarify several sociopolitical issues regarding the Central Asian region. Do we detect a new approach that Russia, together with India and China, uses to form a multipolar world? Will the new Davos forum in Kyrgyzstan attract the leaders of the most influential Central Asian countries, and become as representative as its European prototype? Late 2014 was marked by the signing of several bilateral agreements during Summits involving Russia, India and China. According to numerous international experts, improved relations between Moscow and the two Asian giants (China and India), represents another big step in transforming a unipolar world order with the USA as the only leading country into a multipolar world. The analysis of the main reasons for Beijing and New Deli becoming closer with Moscow will start with the complications in Russia-US relations. One of the reasons for Russia-West relations becoming colder is the position of Russia in the Ukrainian crisis, which resulted in Russian leadership reaching a decision to expand their foreign policy vector in Eastern direction. With that said, tighter connections of Russia, China and India fully reflects long-term interests of those countries. Despite several questionable moments in Russian foreign policy in Eastern Europe and Near East, Beijing and New Deli view Russia as a reliable partner for further dialogue, cooperation and trade. The Russia-China cooperation, since 1990s, is actively developing, while strategic Russia-India partnership still maintains the image of the USSR era, when the Cold War took place. We also cannot discount the fact that Russia, India and China are already working together in many international organizations, like the BRICS forum (Brazil, Russia, India, China, South Africa, and, on this basis, they already have opportunities to develop new platforms for political, economic, and military cooperation, like the Shanghai Cooperation Organization. At the same time, the Russia-India-China strategic triangle already has a huge potential for combining efforts to achieve mutual goals, which can, in turn, give birth to a new model of international dialog, signature for the newly-forming multipolar world.

Keywords: politics, international security, geopolitics, trend, state, security, diplomacy, international relations, international life, interests.

Аннотация. Настоящая статья посвящена внесению ясности в ряд важных общественно-политических вопросов, касающихся Центральноазиатского региона. Является ли это новым русским подходом, реализуемьм совместно с Китаем и Индией вектором формирования многополярного мира? Будет ми новый Аавосский форум, который соберет в будущем лидеров наиболее влиятельных иентральноазиатских государств в Кыргызстане, столь же авторитетным и представительным, как его европейский прообраз? Конеи 2014 года был отмечен заключением ряда существенных двусторонних соглачений в ходе встреч на высшем уровне с участием России, Индии и Китая. По мнению многих международных аналитиков, улучшение отношений Москвы с двумя азиатскими гигантами (Китаем и Индией) представляет собой еще один еще один щаг $\kappa$ глобальной трансформации от однополярного мирового порядка с единственным мидером - США - кмногополярному миру. Отправной точкой для анализа основных причин уяучшения отнотений Пекина и Нью-Аели с Москвой явмяются те трудности, которые имели место быть в двусторонних отношениях между Россией и США. Одной из причин охиаждения отношений между Россией и Западом стала позиция России в отношении кризиса в Украине, что в итоге побудило российское руководство развернуть вектор своей внешней политики на Восток. Однако, сбликение России, КНР и Индии полностью отвечает долгосрочным начиональным интересам участников этого сближения. Несмотря на некоторые спорные моменты политики России в Восточной Европе и на Ближнем Востоке, Пекин и Нью-Аели смотрят на Россию как на надежного партнера, с которым они готовы продолжать диалог, сотрудничать и торговать. Российско-китайское сотрудничество интенсивно развивается начиная с 1990-х годов, в то время как стратегические индийскороссийские отношения все еще сохраняют облик сотрудничества, выработанный в годы существова- 
ния СССР, в период холодной войнь. Кроме того, нельзя недооиенивать тот факт, ито Россия, Индия и Китай уже активно взаимодействуют и в других многосторонних организаций, таких, как БРИКС форуме (Бразилия, Россия, Индия, Китай, Южнал Африка), и на базе этих организаиий уже есть возможность для разработки новых платформ политического, экономического и военного сотрудничества, например в рамках Шанхайской организации сотрудничества (ШОС). В то же время, стратегический треугольник Россия-Индия-Китай (РИК) в настоящее время обладает огромным потенциалом дяя кооперачии усилий образующих его стран ради достижения общих иелей, что может породить новую модель межгосударственного диалога, харатерную для формирующегося многополярного мира.

Кнючевые слова: политика, международная безопасность, геополитика, Тренд, государство, безопасность, дипломатия, международные отночения, международнал жизнь, интересь.

\section{THE STRENGTHENING OF RUSSIAN- CHINESE COOPERATION}

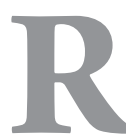

egarding the close relationship between

China and Russia, it is possible to consider latest agreements on energy co-operation, taking into consideration that improvements of this relation have been underway for about two decades after the fall of Soviet Union. It can be argued that Russian-Chinese partnership is based on three basic pillars, key points of Chinese foreign policy: peace, cooperation and development, to which it's possible to add mutual profit for both sides and «win-win strategy».

Milestone of last year improvements in bilateral relations was May 2014 agreement worth $\$ 400$ billion, which concerns pipeline Power of Siberia and the sending of 38 billion cubic meters of natural gas from Russia to China. The sale of gas will not begin immediately because natural gas fields in Eastern Russia require infrastructural improvements as well as connecting pipelines have yet to be installed. However, according to agreements the sending of natural gas through the eastern route will be operative from 2018 .

Russia and China have also signed a Memorandum of Understanding for the western route, which could guarantee to China further 30 billion cubic meters of natural gas per year. The main important consequence of these agreements is that they could transform China in the largest consumer of Russian gas. An aspect that should not be underestimated in a consideration of medium-long term is that China could become the main market of Russian energy resources as a whole, overcoming Europe. In 2012 Russian exports of natural gas towards Europe totaled $\$ 66$ billion and accounted for more than $10 \%$ of total Russian exports. In the diversification of its exports, Russia could find in Chinese market a viable alternative to Europe, while the latter should find clear alternatives such as shale gas from United States reducing its energy dependence from Russia.

At the same time, there is an important strategic advantage for Beijing because it would receive resources through land. This would be a major transformation of Chinese energy supplying, considering that currently resources destined to China are transported by sea through the Strait of Malacca, controlled by United States, and through areas characterized by tensions and territorial disputes (South and Eastern China Sea).

Becoming a fundamental energy partner of China, Russia would be also a competitor of United States since Chinese territory is one of the most advantages markets for Washington's exportations of Liquefied Natural Gas (LNG). Energy sector represents the most important area in which Russian-Chinese cooperation could further develop: for example Rosneft has offered a $10 \%$ stake to Chinese authorities for the project of joint exploitation of Vankor oil field in Eastern Siberia, Rosneft's third-largest onshore production subsidiary. This deal would represent the most substantial Chinese equity participation in Russia's onshore oil industry to date. Furthermore, it will be offered a representative office to China in the board of the same project, while Moscow would offer the sale of oil from Vankor's field with payments in Yuan, a move that would exemplify a challenge to international dollar system and its role as reserve-currency in the world.

China aims to invest in Asian infrastructural sector with the ambitious objective to create a complex network of high-speed railways, pipelines, ports and optical fibers cables that could link Chinese cities to neighboring countries and beyond; in this case two projects could be cited, the Silk Road Economic Belt through Eurasia 
and the 21st Century Maritime Silk Road trough East and South China Seas and Pacific and Indian Oceans. These projects could effectively link Europe to Asia-Pacific. Some components of these plans are already under construction, especially in Central Asian republics, but Chinese intentions are to create more links with Russia, Iran, Middle East, Turkey, Indian Subcontinent, South-East Asia and Europe.

The current Asian political scenario, considering these Chinese infrastructural projects, is then characterized by the consolidation of a strategic cooperation between Russia and China, a factor confirmed at the end of the last meeting between APEC countries (Asia-Pacific Economic Cooperation), hosted by Beijing (November 10th - 11th, 2014). This strategic cooperation has been further emphasized by visit of Russian Defense Minister Sergey Shoigu in Beijing few days after APEC summit. From all these meetings and subsequent agreements emerged the prospect of an alliance based on common economic, military, political and energy interests in order to share development and stability in the Asia-Pacific region. This cooperation could also appear to some extent as a political response to NATO's containment of Russia and US pivot strategy finalized to rebalance of power in Asia-Pacific. This particular kind of interpretation focused on Washington's concerns is founded analyzing Eastern Europe's tensions and sporadic diplomatic clashes for the economic control of East and South China Seas.

China looks favorably to economic consequences arising from its cooperation with Russia. The international situation and concerns related to strategic issues have created the conditions for a strengthening of teamwork between Russia and China so that Moscow could defend its interests and Beijing could maintain globally a balance of power. It is possible that this kind of collaboration could go further, making the two countries interdependent and able to reinforce relationship in other sectors (agriculture, aerospace, defense and information technology). Russia and China have already a consolidated business relationship worth approximately $\$ 100$ billion and at the same time China could support Moscow to deal with the effects of Western sanctions on its finances. Beijing would continue to invest in Russian bonds and make direct investments in Russia. China is currently in the position to do so, given the availability of foreign exchange reserves (more than $\$$ 4,000 billion).

Additionally, as demonstrated by the visit of Russian Defense Minister Shoigu to Beijing the Russian-Chinese cooperation will be strengthened in other fronts such as that of the military cooperation, which could be implemented considering common concerns related to cited US Pivot to Asia. As announced by Shoigu during 2015 there will be Russian-Chinese joint naval exercises not only in the Pacific, but also in the Mediterranean Sea.

This is a deliberate long-term Russian strategy to leave behind cooperation with Europe and United States or is a merely tactic searching a revitalization of relations with the West? It's likely that Russia contemplates strengthening of partnership with Beijing as a useful alternative to relationship with Europe, but also to counterbalance US role in Asia-Pacific. However, the whole scenario is more multifaceted, given the complexity of Sino-US relations and the economic interdependency between Washington and Beijing. Tensions between Russia and West could be exploited to its advantage by China. Given the all picture, another point to consider is in fact that China does not intend to completely sever its relations with Washington coming to a strategic rivalry between blocks typical of Cold War period. The complexity of SinoAmerican relations is evident, given the value of economic cooperation and common concerns on various global issues (Islamic terrorism, the future of Afghanistan, Iran's nuclear issue and agreements on global warming). The current global context is not characterized by the presence of ideological opposing blocs, but can be rather be described as an evolving multipolar system characterized by power centers interdependent with an increasingly significant role of Asian countries.

\section{THE LONG-TERM SYNERGY BETWEEN INDIA AND RUSSIA}

After China, Moscow maylook to other alternatives to Europe for its natural resources exportations, considering a strengthening of relations with Japan, South Korea and India.

In the specific case of India, the Sino-Russian energy pact could be followed by a similar cooperation between Moscow and New Delhi. Narendra Modi, the new prime minister of India in charge 
from last May 2014, is searching to improve relationships with many global and regional actors, like United States, China and Japan. Russia is another important partner, to which current India's government looks with deep attention in a changing international environment. At the same time it's thanks to Vladimir Putin that from the end of nineties Russia-India strategic partnership had new force after the fall of Soviet Union.

A stronger Indo-Russian energy relation could significantly change the political equilibriums of Asian continent. This kind of cooperation would be focused on natural gas and in particular in the importation by India of LNG, despite the need of infrastructural improvements in Indian and Russian territories. Since India has limited reserves of natural gas, it would be for New Delhi a concrete opportunity to diversify its energy supply and a necessary provision in order to support economic growth and meet rising domestic demand of energy resources. However energy collaboration could also involve Russian oil.

Nevertheless, there are a number of political issues that could hinder Indo-Russian energy cooperation. Russia negative relations with Western countries represent a counterproductive aspect for India and an expected tightening of Western sanctions against Russia linked to Ukrainian situation could affect the activity of certain Indian public companies with interests in dealing with Russian counterparts, such as $\mathrm{Oil}$ and Natural Gas Corporation Limited (ONGC), Gas Authority of India Limited (GAIL) and Bharat Petroleum (BP). ONGC's interests to drill shale oil in Siberia could be delayed because sanctions against Moscow make it more problematic to work with US counterparts, given the fact that last September 2014 Washington banned its companies from supporting exploration and productive activities in deep water, Artic offshore and shale projects in Russia. This problematic situation could affect ONGC's activity because it has contracted US firm Liberty Resources to drill four wells in the Bazhenov shale formation in Siberia, a project that now could be interrupted. ONGC has also a $20 \%$ stake in the Sakhalin 1 project in Russia and is in consultations with Rosneft over a stake in two east Siberian oil fields and it could look out for alternative solutions for drilling in the Bazhenov.
GAIL company, the nation's largest natural gas distributor, has recently signed several agreements with some US corporations, for example the pact with US-based WGL for buying about 2.5 million tons of gas for twenty years. GAIL may incur therefore in problematic situations in the case of business activity with Russian firms, for example Gazprom held discussions with GAIL for deliveries also of Russian LNG.

While it's true that India has other public companies that haven't developed agreements outside of the Subcontinent and could benefit from an effective Indo-Russian energy cooperation, United States see adversely the developments of New Delhi-Moscow relations. Washington has publicly expressed its disappointment in the aftermath of the positive 15th Indo-Russian bilateral summit held last December in New Delhi, arguing that this is not a good time «to make business with Russia as usual».

New Delhi has not approved Western sanctions against Russia, but at the same time it has not yet recognized Crimea as an effective part of Russia, though refusing to criticize openly Moscow. At this particular juncture it's clearly emerging an Indian intention to maintain a substantial strategic autonomy and a difficult balance position in its approach towards United States and Russia. Though, it's at the same time clear that Washington has used and will continue to apply sanctions to commercial activities related to energy sector as a political tool to isolate opponents (for example Iran in the past for nuclear issue and Russia today for Ukrainian situation), pressuring its allies (for example India) to stop commercial activities with these antagonists States that have to change a specific political behavior according to Washington strategic calculus. Iran's case of few years ago is emblematic: New Delhi as a result of US pressure supported sanctions against Tehran regarding nuclear issue, partially spoiling Indo-Iranian traditional good cooperation. If it is true that in that case sanctions had United Nations assent and India is against unilateral sanctions, it is certainly not to be underestimated US irritation towards India's attempts to improve relations with Russia.

At the last Indo-Russian bilateral summit the two countries signed twenty agreements - seven intergovernmental and thirteen commercial including a strategic vision for a peaceful coop- 
eration in the use of atomic energy. In summary, agreements have concerned energy sector, fields of technology and innovation and they promoted a wide-ranging engagement in commercial activities, considering the use of national currency for bilateral trade. According to Vladimir Putin's statements, Russia will support India in the construction of twelve nuclear power plants after the positive results related to Kudankulam nuclear power project and the oil company Rosneft will start to send ten tons of oil per year. Russian authorities offered to build in India one of the most advanced Russian helicopters and it will speed up the implementation of the joint project for the fifth-generation fighter jet. Russia aims also to participate in the plan for the realization of Delhi-Mumbai Industrial Corridor and facilitate the process of India's accession to SCO. However, trade is declining and it's equal to $\$ 11$ billion; for a comparison, Indo-Chinese bilateral commerce is about 70 billion, while Sino-Russian stands around 100 billion. In this sense, negotiations to promote a free trade agreement between India and Eurasian Union could be seen as a measure suitable to boost bilateral commerce. It's also important that the project for North-South Transport Corridor (involving Russia, India and Iran) would be effectively implemented since the intentions of a commerce network that could integrate South Asia, Iran, Central Asia and Russia. The geographical distance between India and Russia is significant, but last bilateral summit showed willingness in both sides to overcome this particular difficulty. The basic idea is to encourage a transformation of bilateral cooperation in a much better quality, observing also the international framework and supporting the development of a collective, balanced and inclusive security in Asia-Pacific, considering the legitimate interests of all States in a region led by the respect of international law.

Narendra Modi has recently affirmed the importance and priority assigned to Moscow in the strategic calculus of New Delhi, claiming that Russia will remain the most important partner of India in defense sector. The Indian government is also interested to enhance cooperation with Russia in spite of sanctions sponsored by Washington. However, it is important to underline that Modi is keen to have stronger defense ties with US the main partner in the sector of arms imports in recent years during Manmohan Singh government - although it's not possible at this moment to replace Russia's role. At the same time Moscow is looking to Pakistan, which could become a strategic military partner of Russia. Another aspect is that Russian-Chinese partnership could be seen with concern by New Delhi: Russian technologies and systems are now exported also to China, not only to India, and a rising Chinese power could transform Asian balance of power, pushing India towards United States.

Nevertheless, India seems interested to promote a deep cooperation with Russia, which could aspire to become one of the countries most concerned in governmental campaign $\ll$ Make in India» launched by Modi and designed to accelerate the economic growth of the country and particularly to support the Indian manufacturing sector by attracting foreign direct investment. In this case the nature of Indo-Russian cooperation could be transformed by purchaser-consumer structure to joint manufacturing partners.

The recent meeting between Putin and Modi, as well as summits and agreements between Russian and Chinese authorities are particularly important for the period in which they occurred, few months after the inauguration of a new government in India andwith the specter of a «New Cold War» between West and Russia, though the use of the term «Cold War» in order to describe the current standoff of US-Russian relations is not totally correct.

There are different expectations from Russian government that new course in India will fortify Indo-Russian partnership and many signals go in this direction; as well as it could be possible a strategic alliance with China, considering many fields of joint cooperation. The world order is changing and Western countries should take into account the complex network of relations involving Russia, India and China and other Asian countries. These regional powers are no longer only spokesman of an emergent world seeking voice in an anachronistic international system, considering for example India and China aspirations to reorganize board of United Nations, World Bank and International Monetary Fund. Furthermore, Russia, India and China are not only characters of multilateral forums such as BRICS or G-20, but they are already proponents of deep bilateral 
relations and bearer of new systems of payment in international trade, considering the use of national currencies than could potentially change future global balances of power. These are clear exemplifications of the emergence of a multipolar world order ${ }^{[1]}$.

\section{БИБАИОГРАФИЯ}

1. www.moderndiplomacy.eu

2. Карякин В.В. Цивилизационная антропология американского экспансионизма: от доктрины Монро к глобальному мидерству / / Международные отношения. - 2013. - 4. - С. 487-468. DOI: 10.7256/2305-560X.2013.4.9722.

3. Карпович О.Г. МежАународные организации и их роль в предупреждении, урегулировании и разрешении этнополитических конфмиктов // Национальная безопасность / nota bene.2014. - 3. - C. 398-405. DOI: 10.7256/2073-8560.2014.3.11786.

4. Карякин В.В. Совреемнные кризисы и конфмикты: особеннсоти, сценарии развития и предотвращение // Международные отношения._2014._-3.— C. 446-457. DOI: 10.7256/2305560X.2014.3.11422.

5. Калачев А.Н. Современная система международной безопасности: средовые параметры // МеЖАународные отношения. - 2014. - 4. - C.544-549.DOI: 10.7256/2305-560X.2014.4.13243.

6. Галвес Аеромле П. Brazil — New Age // Конфмиктология / nota bene. - 2014. - 1. - С. 136139. DOI: $10.7256 / .2014 .1 .13181$.

7. Фельдман П. Я. Геополитический клиентелизм в межАународных отношениях: стратегия и тактика Запада. / / Международные отношения. - 2014._-2._- С. 189-193. DOI: 10.7256/2305560X.2014.2.11365.

8. Манойло А.В. Роль стратегий управмяемого хаоса в формировании нового миропорядка // Право и политика. - 2014. - 5.- C. 638-651. DOI: 10.7256/1811-9018.2014.5.11816.

9. Курилкин А.В. Современные подходы к ведению информационных войн / / Международные отношения. - 2014. - 1.— C. 75-80. DOI: 10.7256/2305-560X.2014.1.10063.

10. Виноградова Е. А. Информационные войны в Аатинской Америке / / Тренды и управление.2014.-4.— C. 372-384. DOI: 10.7256/2307-9118.2014.4.13080.

11. Валиуллин И.И. Эволюция понятия «информационная война» в политической науке // МежАународные отношения. - 2014. - 1._ C. 68-74. DOI: 10.7256/2305-560X.2014.1. 10064.

12. Карпович О. Г. ГАобальные проблемы международных отношений в контексте формирующегося многопомярного мира / / Право и политика. — 2014. - 5. - С. 620-629. DOI: 10.7256/18119018.2014.5.11787.

13. Гуаньцюнь $\Lambda$. Роль тайваньской проблемы в морской политике КНР // Международные отношения. - 2013. - 4. - C. 469-509. DOI: 10.7256/2305-560X.2013.4.9754.

14. Афанасьев В.В. Современные мокальные конфмикты // МежАународные отношения. - 2014. 1.- C. 56-61. DOI: 10.7256/2305-560X.2014.1.10061.

\section{REFERENCES (TRANSLITERATED)}

1. www.moderndiplomacy.eu

2. Karyakin V.V. Tsivilizatsionnaya antropologiya amerikanskogo ekspansionizma: ot doktriny Monro k global'nomu liderstvu // Mezhdunarodnye otnosheniya. - 2013. - 4. - C. 487-468. DOI: 10.7256/2305-560X.2013.4.9722.

3. Karpovich O. G. Mezhdunarodnye organizatsii i ikh rol»v preduprezhdenii, uregulirovanii i razreshenii etnopoliticheskikh konfliktov / / Natsional'naya bezopasnost » / nota bene. - 2014. 3.- C. 398-405. DOI: 10.7256/2073-8560.2014.3.11786.

4. Karyakin V.V. Sovreemnnye krizisy i konflikty: osobennsoti, stsenarii razvitiya i predotvrashchenie // Mezhdunarodnye otnosheniya. - 2014. - 3. - C. 446-457. DOI: $10.7256 / 2305-$ 560X.2014.3.11422. 
5. Kalachev D. N. Sovremennaya sistema mezhdunarodnoi bezopasnosti: sredovye parametry // Mezhdunarodnye otnosheniya. - 2014. - 4. - C. 544-549. DOI: $10.7256 / 2305-$ 560X.2014.4.13243.

6. Galves Derolle P. Brazil — New Age / Konfliktologiya / nota bene. - 2014. — 1. — C. 136-139. DOI: $10.7256 / .2014 .1 .13181$.

7. Fel'dman P. Ya. Geopoliticheskii klientelizm v mezhdunarodnykh otnosheniyakh: strategiya i taktika Zapada. // Mezhdunarodnye otnosheniya. - 2014. - 2. - C. 189-193. DOI: 10.7256/2305560X.2014.2.11365.

8. Manoilo A.V. Rol» strategii upravlyaemogo khaosa v formirovanii novogo miroporyadka // Pravo i politika. - 2014.— 5. - C. 638-651. DOI: 10.7256/1811-9018.2014.5.11816.

9. Kurilkin A. V. Sovremennye podkhody k vedeniyu informatsionnykh voin // Mezhdunarodnye otnosheniya. - 2014. - 1._ C. 75-80. DOI: 10.7256/2305-560X.2014.1.10063.

10. Vinogradova E. A. Informatsionnye voiny v Latinskoi Amerike // Trendy i upravlenie. - 2014. 4.-C. 372-384. DOI: 10.7256/2307-9118.2014.4.13080.

11. Valiullin I. I. Evolyutsiya ponyatiya «informatsionnaya voina» v politicheskoi nauke // Mezhdunarodnye otnosheniya._-2014.-1.-C.68-74.DOI: 10.7256/2305-560X.2014.1.10064.

12. Karpovich O.G. Global'nye problemy mezhdunarodnykh otnoshenii vkontekste formiruyushchegosya mnogopolyarnogo mira // Pravo i politika. - 2014. - 5. - C. 620-629. DOI: 10.7256/18119018.2014.5.11787.

13. Guan'tsyun» L. Rol» taivan'skoi problemy v morskoi politike KNR // Mezhdunarodnye otnosheniya. - 2013. - 4.— C. 469-509. DOI: 10.7256/2305-560X.2013.4.9754.

14. Afanas'ev V.V. Sovremennye lokal'nye konflikty / / Mezhdunarodnye otnosheniya. — 2014. — 1. C. 56-61. DOI: 10.7256/2305-560X.2014.1.10061. 